\title{
Organic functionalization of single-walled carbon nanotubes (SWCNTs) with some chemotherapeutic agents as a potential method for drug delivery
}

\author{
This article was published in the following Dove Press journal: \\ International Journal of Nanomedicine \\ 28 August 2010 \\ Number of times this article has been viewed
}

\author{
Ardeshir Khazaei' \\ Mohammad Navid Soltani Rad ${ }^{2}$ \\ Maryam Kiani Borazjani' \\ 'Faculty of Chemistry, Bu-Ali \\ Sina University, Hamedan, Iran; \\ ${ }^{2}$ Department of Chemistry, Faculty \\ of Basic Sciences, Shiraz University \\ of Technology, Shiraz, Iran
}

\begin{abstract}
The grafting of drugs to the single-walled carbon nanotube (SWCNT) was attained by the initial conversion of carboxylic groups in SWCNT to corresponding acyl chlorides. The active acyl chlorides in SWCNT were subsequently mixed with chemotherapeutic agents having $\mathrm{NH}$, $\mathrm{NH}_{2}$, and $\mathrm{OH}$ functional groups to afford the formation of relevant amide and ester, respectively. The covalently grafted drugs to SWCNT were identified by infrared and UV-visible spectroscopy and transmission electron microscopy methods. From a clinical aspect, the grafting of drugs to the SWCNT can be used as a new tool and useful method for potential drug delivery in patients.
\end{abstract}

Keywords: grafting of drugs, solubilization

\section{Introduction}

Slow release is critically significant in drug delivery for minimizing the amount of drug lost before reaching the target. Shell structures and supports can be used for slow delivery of drugs and are usually made from organic materials. For example, liposomes, ${ }^{1-3}$ microspheres, ${ }^{4}$ polymeric shells, ${ }^{5}$ and polymeric micelles ${ }^{6,7}$ have been well investigated. In constructing a drug delivery system from organic materials, the combinations of shell or support materials, targeting molecules, and drugs are restricted to ensure stability, targeting efficiency, and drug effect. Although, many supporting polymers are expensive, this restriction can be reduced by using carbon nanotubes (CNTs). ${ }^{8}$ On the other hand, nanomedicine, which is an emerging bridge linking nanotechnology and advanced medical technology, involves the exploration of nanoscaled materials with the aim of developing novel types of drug carriers, imaging agents, sensors, etc. ${ }^{9,10}$

Nanotubes have several properties that make them suitable for use as nanotube-supported drugs. Functionalized CNTs have been shown in many studies to be able to cross cell membranes. ${ }^{11-13}$ The ability of CNTs to cross cell membranes allowing them to be used as carriers is of particular high interest for drug delivery strategies. In targeting the delivery of drugs to cells, the drugs are first attached to the carrier by either covalent or noncovalent bonding. The drug carrier conjugates are then directed to the targeted cells via passive targeting methods (ie, a methodology to increase the target/nontarget ratio of the amounts of drugs delivered primarily by minimizing nonspecific interactions with nontarget organs, tissues, and cells) or active targeting methods (ie, the method by which the therapeutic agent is delivered to tumors by attaching the agent with a ligand that binds to specific receptors that are overexpressed on target cells).${ }^{14}$ After reaching the targeted site (organs, tissues, or cells), there are 2 possibilities: (1) the drug is internalized (ie, enters the cells) without 
internalization of the carrier or (2) both the drug and the carrier are internalized. The latter internalization method has greater delivery efficacy because after entering the cells, the intracellular environment will degrade the drug-carrier conjugate, releasing drug molecules inside the cells. On the other hand, in the former internalization method, the extracellular environment helps degrade drug-carrier conjugates, and the drug will then cross the lipid membrane to enter the cells. CNTs with the ability to cross cell membranes are good candidates to serve as drug delivery carriers to cells with high efficacy. ${ }^{15}$ Also, negative mutagenic and clastogenic potentials suggest that single-walled carbon nanotubes (SWCNTs) and single-walled carbon nanohorns (SWCNHs) are not carcinogenic. For example, the acute per oral toxicity of SWCNHs was found to be quite low. ${ }^{16-18}$ The lethal dosage for rats was more than $2,000 \mathrm{mg} / \mathrm{kg}$ of body weight. Intratracheal instillation tests revealed that SWCNHs rarely damaged rat lung tissue in a 90-day test period, although black pigmentation due to the accumulation of SWCNHs was observed. ${ }^{19}$ In recent years, biological applications for carbon nanomaterials, including SWCNHs and fullerene, have come under close scrutiny. ${ }^{11,20-24}$

SWCNHs and SWCNTs have extensive surface areas. Multitudes of horn interstices in SWCNHs enable large numbers of guest molecules to be adsorbed in a nonbonded way; however, to the best of our knowledge, the covalent grafting of drugs to the SWCNT has not been reported so far. Herein, we report the ability of SWCNTs for the covalent grafting of drugs to their active sites (Figure 1).

The medicinal standpoint of this present research is covalent grafting of drugs to SWCNTs, which can be considered a new method for potential drug delivery. This would be achievable by preparing several pastes that can be applied on the skin similar to a label. Hydrolysis reaction occurs, and the drug is absorbed through the skin long time intervals after the application of the paste. ${ }^{25}$ This process, therefore, enables the slow administration of medications for longer periods. This can help patients who have problems associated with oral administration and injection of drugs.

The solubility of products obtained in this work is also an important subject. The solubility of SWCNTs in aqueous and

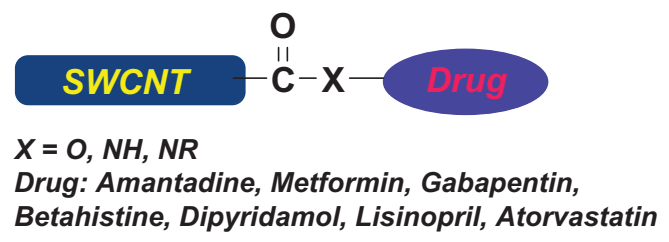

Figure I Covalent grafting of various drugs to the SWCNT. organic solvents has been previously studied by functionalizing the SWCNTs with various organic moieties. ${ }^{26}$

\section{Materials and methods Materials}

The pure SWCNTs in their closed cap shape without functional groups were purchased from Petrol Co. (Tehran, Iran) (Figure 2). $\mathrm{SOCl}_{2}, \mathrm{HCl}, \mathrm{H}_{2} \mathrm{SO}_{4}, \mathrm{HNO}_{3}, \mathrm{H}_{2} \mathrm{O}_{2}(30 \mathrm{wt} \%$, aq), deionized water, $\mathrm{NaH}(80 \%)$, anhydrous dimethylformamide (DMF), $\mathrm{CaH}_{2}$, anhydrous $\mathrm{Na}_{2} \mathrm{SO}_{4}$, and phosphate-buffered saline (PBS; $\mathrm{pH}=1.3$ ) were obtained from Sigma Aldrich and Merck. Cellophane membrane dialysis bag was purchased from Polymer Co. (Tehran/Iran). Drugs, such as amantadine, metformin, gabapentin, betahistine, dipyridamol, lisinopril, and atorvastatin, were purchased from Sobhan Darou Co. (Tehran, Iran).

\section{Functionalization of SWCNTs}

To functionalize the SWCNT with drugs having amino and/ or hydroxyl moieties, we followed a methodology already demonstrated by several literatures. ${ }^{26-30}$

The first step was cracking and oxidation of the SWCNTs. For every $0.1 \mathrm{~g}$ of full-length SWCNT, $50 \mathrm{~mL}$ mixture of 3:1 (vol/vol) concentrated $\mathrm{H}_{2} \mathrm{SO}_{4}$ and $\mathrm{HNO}_{3}$ was added, and the SWCNT-acid mixture was then subjected to reflux at temperature between $65^{\circ} \mathrm{C}$ and $70^{\circ} \mathrm{C}$ for 30 hours.

When the desired time had elapsed, the SWCNT-acid mixture was diluted with a minimum amount of deionized water $(250 \mathrm{~mL})$. The resulting diluted nanotube-acid mixture was then filtered using a $0.45 \mu \mathrm{m}$ polytetrafluoro-ethylene filter (PTFE-millipore) to leave a SWCNT filter cake. The nanotubes were then rinsed with water until a $\mathrm{pH}$ above 5 was obtained. Final rinsing was done using ethanol, and the resulting filter cake was suspended in a 4:1 mixture of $\mathrm{H}_{2} \mathrm{O}_{2}\left(30 \mathrm{wt} \%\right.$, aq) and $\mathrm{H}_{2} \mathrm{SO}_{4}$. The suspension was refluxed

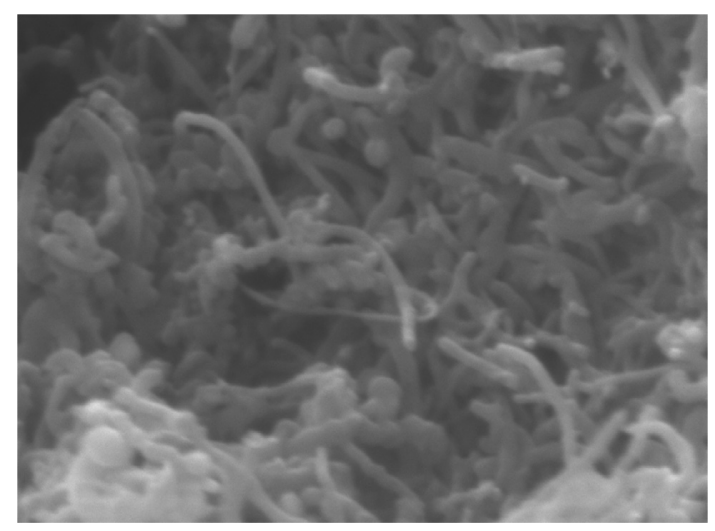

Figure 2 Scanning electron microscopy (SEM) images of SWCNT (without functional groups). 
for 2 hours at $70^{\circ} \mathrm{C}$ to crack the SWCNTs in shorter lengths and, thereby, produce a larger number of opened caps for carboxylation. Concentrated $\mathrm{HCl}$ was then added to the suspension and briefly sonicated to remove the metal catalyst, ${ }^{27-29}$ which resulted in the introduction of terminal carboxyl functional groups, as indicated by infrared measurement $\left(v_{(\mathrm{C}=0)}=1,737 \mathrm{~cm}^{-1}\right.$; spectrum A, Figure 4). The precipitate was stored in a vacuum oven at $180^{\circ} \mathrm{C}$ to remove the water.

The second step was the generation of the acyl chloride functional groups by suspending the purified SWCNT (prepared from the first step) in a solution of freshly distilled thionyl chloride $\left(\mathrm{SOCl}_{2}\right)$ and $\mathrm{DMF}$, which was previously kept in anhydrous $\mathrm{Na}_{2} \mathrm{SO}_{4}$ for 72 hours and distilled in the presence of $\mathrm{CaH}_{2}$. The amounts used in this particular example were $20 \mathrm{~mL} \mathrm{SOCl}$ and $1 \mathrm{~mL}$ DMF per $0.1 \mathrm{~g}$ of SWCNT. This suspension was stirred at $65^{\circ} \mathrm{C}$ for 24 hours. The solid was then separated by filtration and washed with superdried tetrahydrofuran (THF) to remove excess of $\mathrm{SOCl}_{2}$. Subsequently, it was dried in vacuum at room temperature for 5 minutes. The final product was then subjected to functionalization with various drugs.

Drugs having free $\mathrm{OH}, \mathrm{NH}_{2}$, or $\mathrm{NH}$ groups (drug-toSWCNT weight ratio was $15: 1)^{30}$ were mixed with $1 \mathrm{~mL}$ solution of DMF and $\mathrm{NaH}(80 \%)$ and then stirred for 1 hour. The obtained acyl chloride SWCNTs were then added to the suspension. The reaction mixture was kept at $120^{\circ} \mathrm{C}$ for 5 days. The solid was then separated by filtration and washed with deionized water for several times.

The reaction of the drugs with SWCNT and the potential structure of grafted drugs to SWCNTs are summarized in Table 1.

After stirring, a black solid was obtained, which was soluble in DMF and dimethylsulfoxide (DMSO), less soluble in $\mathrm{H}_{2} \mathrm{O}$ and $\mathrm{CH}_{3} \mathrm{CN}$, and insoluble in $\mathrm{CHCl}_{3}, \mathrm{CH}_{2} \mathrm{Cl}_{2}$, acetone, diethyl ether, and hexane (Figure $3 \mathrm{~A}$ and $\mathrm{B}$ ).

Table I Covalent grafting of various drugs to SWCNT

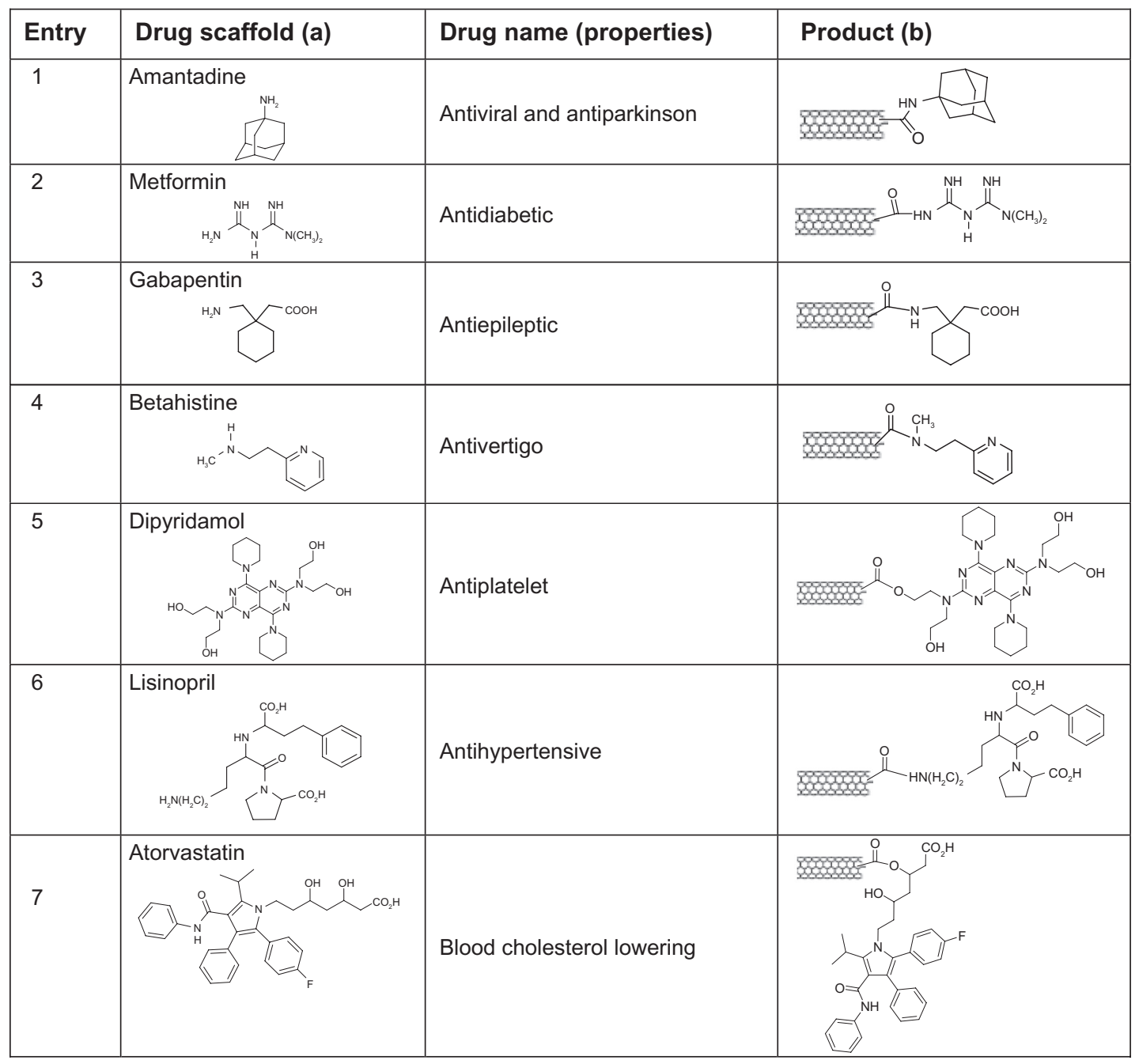




\section{Results and discussion}

We characterized the functional groups present in the covalent drugs grafted to SWCNT by IR and UV-visible (UV-vis) spectroscopy and transmission electron microscopy (TEM) methods after various treatments.

After the initial acid treatment of SWCNT with a mixture of $\mathrm{H}_{2} \mathrm{SO}_{4}$ and $\mathrm{HNO}_{3}$ followed by $\mathrm{HCl}$, the spectrum A was observed (Figure 4). The IR spectrum $\mathrm{B}$ is pertaining to pure betahistine, and the IR spectrum $\mathrm{C}$ (Figure 3) shows the grafted SWCNT-betahistine (entry $4 \mathrm{~b}$, Table 1). The band corresponding to the carboxylic groups present in the acid-treated SWCNT $\left(1,737 \mathrm{~cm}^{-1}\right.$; IR spectrum A, Figure 4) is gradually replaced by bands corresponding to amide bonds $\left(1,663 \mathrm{~cm}^{-1}\right.$; IR spectrum C, Figure 4). Band at $1,699 \mathrm{~cm}^{-1}$ is attributed to water (IR spectrum A, Figure 4). Table 2 summarizes the main bands observed in IR spectra of grafted drugs to SWCNTs.

The UV-vis absorption spectrum of betahistine (Figure 5) displays a loss of features compared with that of SWCNT indicating a disruption in the electronic structure of nanotubes due to the adsorption of betahistine on SWCNT.

TEM studies have revealed the successful grafting of betahistine and other drugs to SWCNT (Figure 6). A large number of the bundles are abundant in functionalized SWCNTs, which are indicated by arrows.

\section{In vitro release of betahistine from grafted SWCNT-betahistine}

Drug releasing from the grafted SWCNT-drug is indeed a hydrolysis reaction, which involves breaking of amide bond in acidic buffer (PBS; $\mathrm{pH}=1.3$ ) at $37^{\circ} \mathrm{C}$. The powdered grafted SWCNT-betahistine $(0.02 \mathrm{~g})$ was added into a cellophane membrane dialysis bag. The bag was closed and transferred into a flask containing $50 \mathrm{~mL}$ of acid buffer. The release of betahistine from grafted SWCNT-betahistine was followed by UV-vis spectroscopy. Figure 7A illustrates

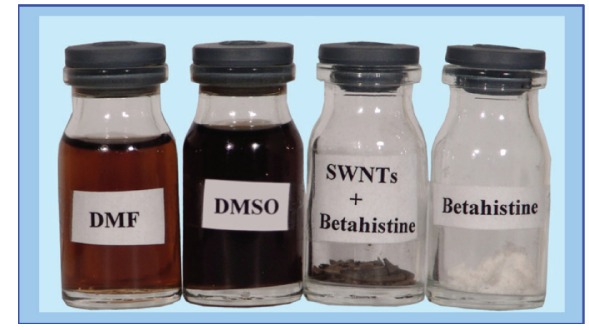

A

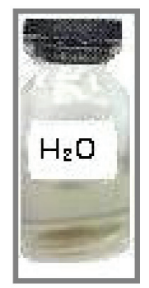

B
Figure 3 Solubility of grafted SWCNT-betahistine A) in dimethylformamide (DMF) and dimethylsulfoxide (DMSO) and $\mathbf{B}$ ) in $\mathrm{H}_{2} \mathrm{O}$. the cumulative dose of betahistine released from grafted SWCNT-betahistine.

\section{Drug loading of betahistine}

A weighed quantity of microspheres was hydrolyzed in 50 $\mathrm{mL}$ acid buffer (PBS; $\mathrm{pH}=1.3$ ). After suitable dilution, the absorbance of samples was measured by UV-vis spectrophotometer at $\lambda=264 \mathrm{~nm}$. The amount of drug was determined from the standard plot of betahistine. The amount of betahistine loaded in SWCNTs' microspheres was determined after complete hydrolysis and was found to be $73 \mathrm{wt} \%$.

\section{In vitro release of dipyridamol from grafted SWCNT-dipyridamol}

The release of dipyridamol from the grafted SWCNTdipyridamol was studied using the same method, which has been described earlier for SWCNT-betahistine. Figure 7B illustrates the cumulative dose of dipyridamol released from grafted SWCNT-dipyridamol.

\section{Drug loading of dipyridamol}

Drug loading of dipyridamol $(\lambda=262 \mathrm{~nm}$ was studied using the same method, which has been described earlier for SWCNT-betahistine, and was found to be $65 \mathrm{wt} \%$. It is interesting to note that the release of dipyridamol from SWCNTs was achieved more smoothly than that of betahistine from SWCNT-betahistine. This can be easily deduced by comparing Figure 7A with Figure 7B.

\section{Conclusion}

In summary, the covalent grafting of some known drugs with different pharmaceutical activities to SWCNTs was achieved by the formation of amides and esters from the drugs having free hydroxyl and/or amino groups mixed with the prepared acyl chloride in SWCNTs. The covalent grafting of drugs increases the solubility of SWCNTs in both aqueous and organic solvents. In vitro release of betahistine and dipyridamol from their corresponding grafted SWCNT adducts was studied, which indicates that drug release can occur smoothly from covalent SWCNT-drug adducts during long time intervals, and this can be considered a useful method for drug delivery.

\section{Acknowledgment}

The authors acknowledge the support from Bu-Ali Sina University Research Council and Center of Excellence in Development of Chemical Methods (CEDCM) for their work. 

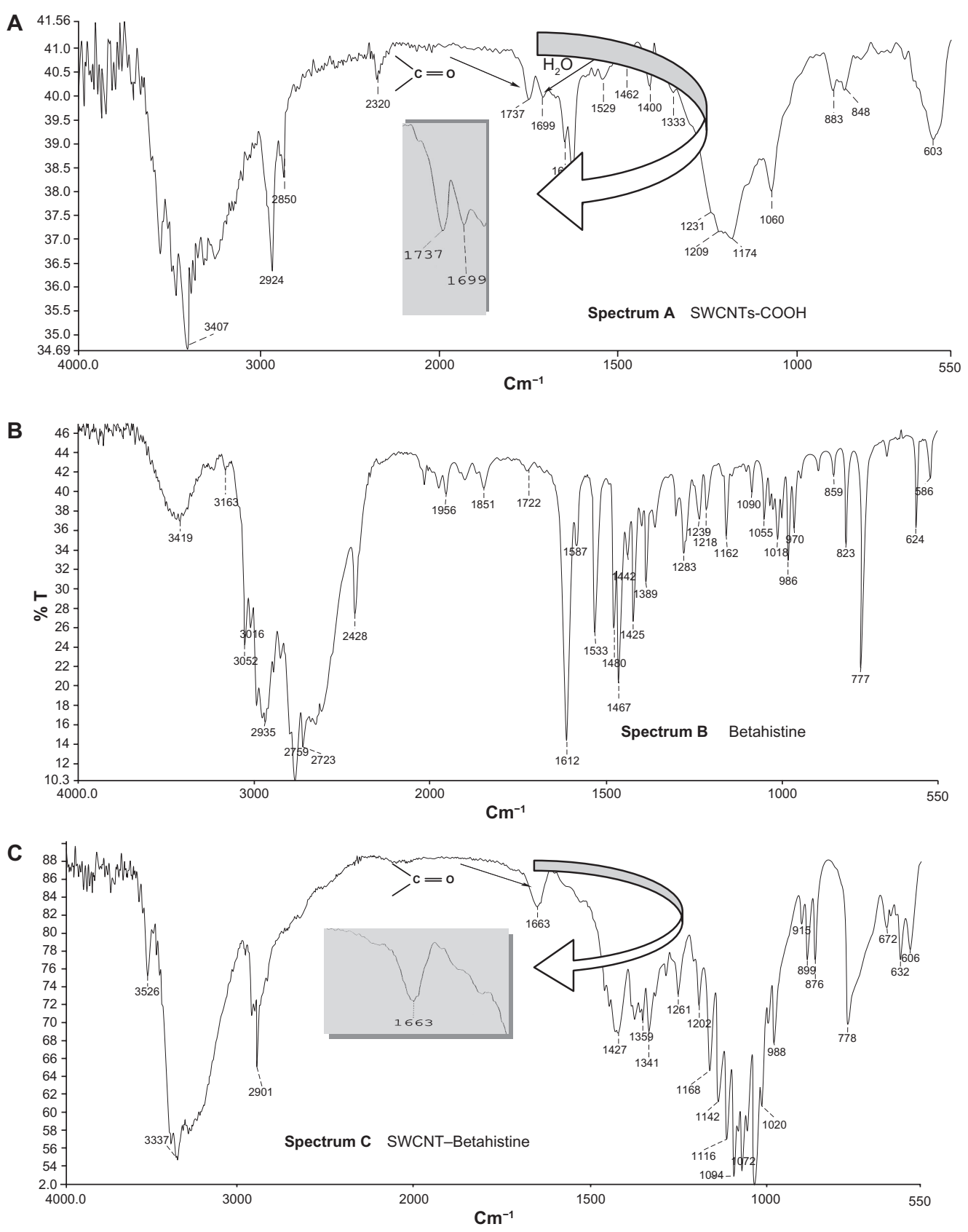

Figure 4 Infrared spectra of A) SWCNT-COOH, B) pure betahistine, and C) grafted SWCNT-betahistine.

Table 2 Infrared absorption bands obtained from the acid-treated SWCNTs and drugs grafted to SWCNTs' solid samples

\begin{tabular}{lll}
\hline Compound & Region $\left(\mathbf{c m}^{-1}\right)$ & Band assignments \\
\hline SWCNT-COOH & 1,737 & Carboxylic acid C=O stretching vibration of SWCNTs \\
Ib & 3,407 & Carboxylic acid OH stretching vibration of SWCNTs \\
2b & 1,630 & Amide $\mathrm{C}=\mathrm{O}$ stretching vibration \\
3b & 1,660 & Amide $\mathrm{C}=\mathrm{O}$ stretching vibration \\
4b & 1,630 & Amide $\mathrm{C}=\mathrm{O}$ stretching vibration \\
5b & 1,663 & Amide $\mathrm{C}=\mathrm{O}$ stretching vibration \\
6b & 1,626 & Ester $\mathrm{C}=\mathrm{O}$ stretching vibration \\
7b & 1,656 & Amide $\mathrm{C}=\mathrm{O}$ stretching vibration \\
\hline
\end{tabular}




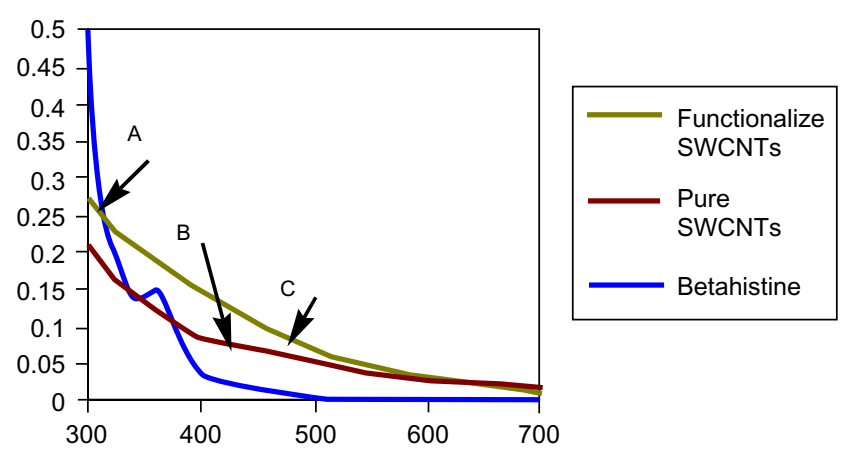

Figure 5 Ultraviolet-visible absorption spectra of $\mathbf{A}$ ) betahistine in dimethylformamide (DMF), B) pure SWCNTs and, C) grafted SWCNT-betahistine (functionalized SWCNTs).
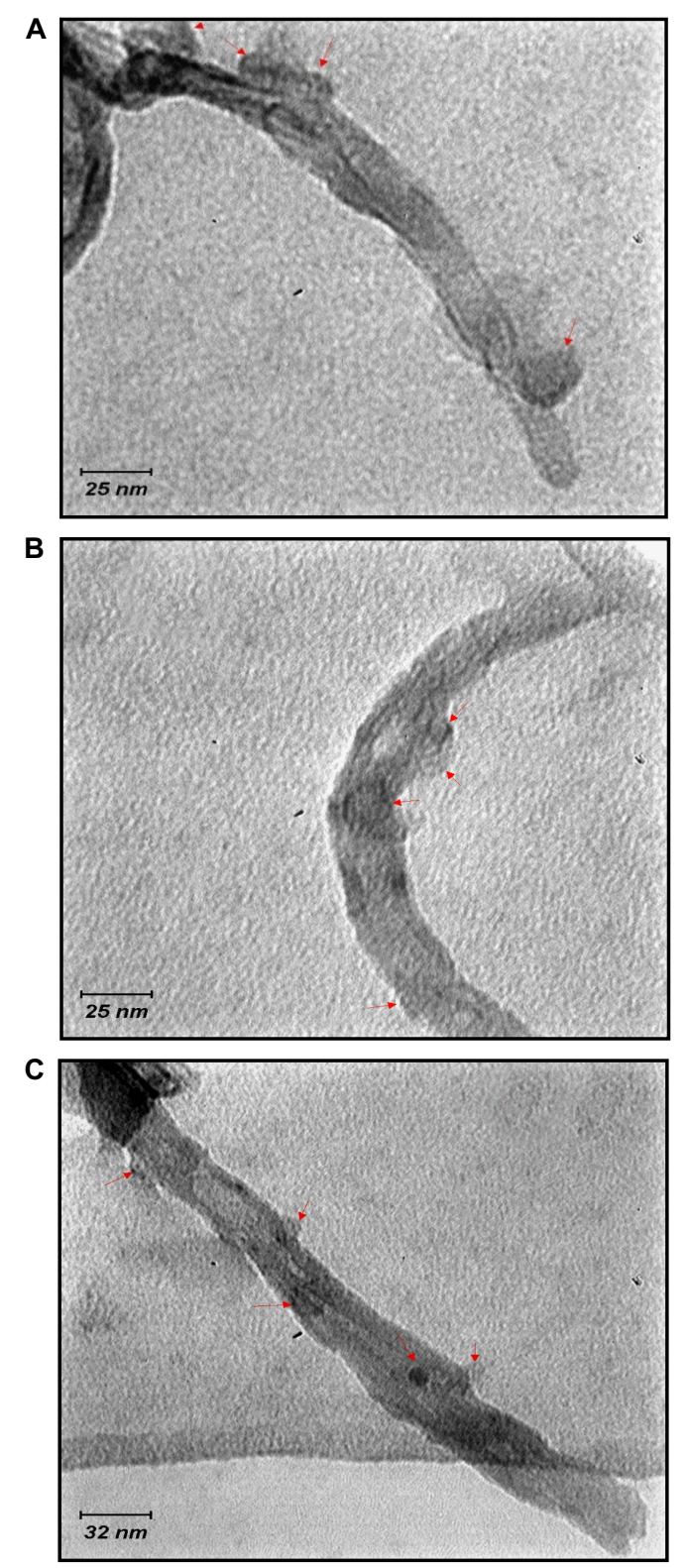

Figure 6 Transmission electron microscopy (TEM) images of A) grafted SWCNTbetahistine, B) grafted SWCNT-dipyridamol, and C) grafted SWCNT-lisinopril (Table I, entries 4b-6b). The arrows indicate the grafted drugs to SWCNT.
A

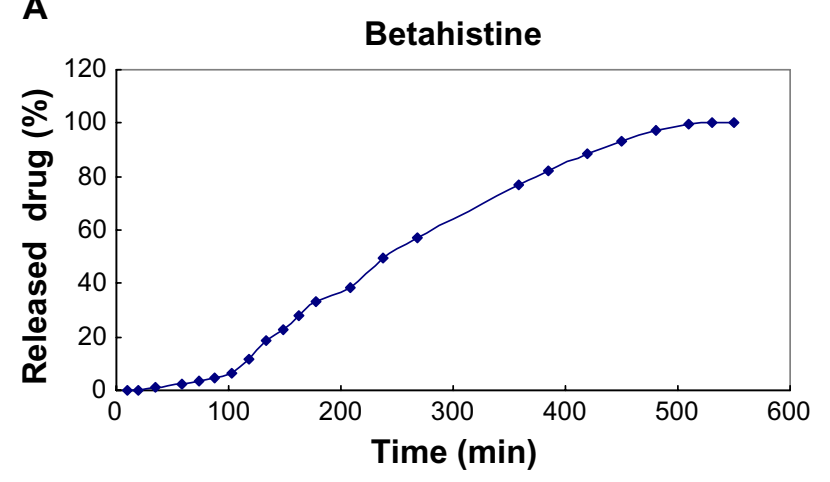

B

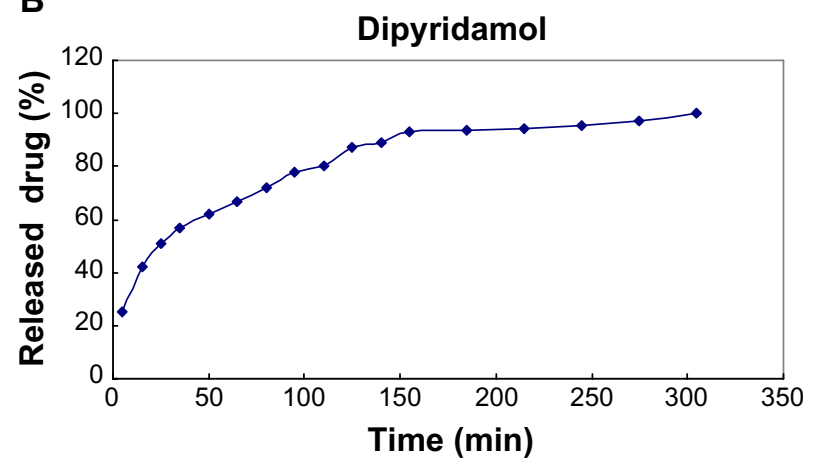

Figure 7 Time course for the cumulative release of A) betahistine and B) dipyridamol from grafted SWCNT-betahistine and SWCNT-dipyridamol, respectively, in phosphate-buffered saline (PBS).

\section{Disclosure}

The authors report no conflicts of interest in this work.

\section{References}

1. Yatvin MB, Weinstein JN, Dennis WH, Blumenthal R. Design of liposomes for enhanced local release of drugs by hyperthermia. Science. 1978;202:1290.

2. Allen TM. Liposomal drug formulations. Rationale for development and what we can expect for the future. Drugs. 1998;56:747.

3. Burger KNJ, Staffhorst RW, de Vijlder HC, et al. Nanocapsules: lipid-coated aggregates of cisplatin with high cytotoxicity. Nat Med. 2002;8:81.

4. Matsumoto A, Matsukawa Y, Suzuki T, Yoshino T, Kobayashi M. The polymer-alloys method as a new preparation method of biodegradable microspheres: principle and application to cisplatin-loaded microspheres. J Control Release. 1997;48:19.

5. Maeda H, Sawa T, Kouno T. Mechanism of tumor-targeted delivery of macromolecular drugs, including the EPR effect in solid tumor and clinical overview of the prototype polymeric drug SMANCS. J Control Release. 2001;74:47.

6. Yokoyama M, Miyauchi M, Yamada N, et al. Characterization and anticancer activity of the micelle-forming polymeric anticancer drug adriamycin-conjugated poly(ethylene glycol)-poly(aspartic acid) block copolymer. Cancer Res. 1990;50:1693.

7. Nishiyama N, Okazaki S, Cabral H, et al. Novel cisplatin-incorporated polymeric micelles can eradicate solid tumors in mice. Cancer Res. 2003;63:8977.

8. Iijima S, Discovery of multi-wall carbon nanotubes. Nature. 1991; 354:56.

9. Moghimi SM, Hunter AC, Murray JC. Nanomedicine: current status and future prospects. FASEB J. 2005;19:311.

10. Ferrari M. Cancer nanotechnology: opportunities and challenges. Nat Rev Cancer. 2005;5:161. 
11. Pantarotto D, Briand JP, Prato M, Bianco A. Translocation of bioactive peptides across cell membranes by carbon nanotubes. Chem Commun. 2004:16-17.

12. Shi Kam NW, Jessop TC, Wender PA, Dai H. Nanotube molecular transporters: internalization of carbon nanotube protein conjugates into mammalian cells. J Am Chem Soc. 2004;126:6850-6851.

13. Kam NWS, O’Connell M, Wisdom JA, Dai H. Carbon nanotubes as multifunctional biological transporters and near-infrared agents for selective cancer cell destruction. Proc Natl Acad Sci U S A. 2005;102:11600-11605.

14. Tran PA, Webster TJ. Nanotechnologies for cancer diagnostics and treatment. In: Dixon CJ, Curtines OW, editors. Nanotechnology: Nanofabrication, Atterning, and Self Assembly. New York, NY: Nova Publishers; 2009 In press.

15. Phong AT, Zhang L, Webster TJ. Carbon nanofibers and carbon nanotubes in regenerative medicine. Adv Drug Deliv Rev. 2009;6: 1097-1114.

16. Constantine PF, Prabhakar RB. Toxicity issues in the application of carbon nanotubes to biological systems. Nanomedicine. 2010;6: 245-256.

17. Bottini M, Bruckner S, Nika K, et al. Multi-walled carbon nanotubes induce T lymphocyte apoptosis. Toxicol Lett. 2006;160:121-126.

18. Shvedova AA, Kisin ER, Porter D, et al. Mechanisms of pulmonary toxicity and medical applications of carbon nanotubes: two faces of Janus? Pharmacol Ther. 2009;121:192-204.

19. Miyawaki J, Yudasaka M, Azami T, Kubo Y, Iijima S. Toxicity of single-walled carbon nanohorns. ACS Nano. 2008;2:213.

20. Yang Z, Zhang Y, Yang Y, et al. Pharmacological and toxicological target organelles and safe use of single-walled carbon nanotubes as drug carriers in treating Alzheimer disease. Nanomedicine. 2010;6(3):427-441.
21. Zhang X, Meng L, Lu Q, Fei Z, Dyson PJ. Targeted delivery and controlled release of doxorubicin to cancer cells using modified single wall carbon nanotubes. Biomaterials. 2009;30:6041.

22. Klumpp C, Kostarelos K, Prato M, Bianco A. Functionalized carbon nanotubes as emerging nanovectors for the delivery of therapeutics. Biochim Biophys Acta. 2006;1758:404.

23. Pantarotto D, Partidos CD, Hoebeke J, et al. Immunization with peptidefunctionalized carbon nanotubes enhances virus-specific neutralizing antibody responses. Chem Biol. 2003;10:961-966.

24. Park KH, Chhowalla M, Iqbal Z, Sesti F. Single-walled carbon nanotubes are a new class of ion channel blockers. J Biol Chem. 2003;278:50212-50216.

25. Wilson CO, Gisvold O, Block JH. Wilson and Gisvold's Textbook of Organic Medicinal and Pharmaceutical Chemistry. 11th ed. Philadelphia, PA: Lippincott Williams and Wilkins; 2004.

26. Niyogi S, Hamon MA, Zhao B, et al. Chemistry of single-walled carbon nanotubes. Acc Chem Res. 2002;35:1105.

27. Fu K, Huang W, Lin Y, Riddle LA, Carroll DL, Sun YP. Defunctionalization of functionalized carbon nanotubes. Nano Lett. 2001;1:439.

28. Marshall MW, Popa-Nita S, Shapter JG. Measurement of functionalised carbon nanotube carboxylic acid groups using a simple chemical process. Carbon. 2006;44:1137.

29. Kim WJ, Kang SO, Ah CS, et al. Functionalization of shortened SWCNTs using esterification. Bull Korean Chem Soc. 2004;25:9.

30. Pompeo F, Resasco DE. Water solubilization of single-walled carbon nanotubes by functionalization with glucosamine. Nano Lett. $2002 ; 2: 369$.
International Journal of Nanomedicine

\section{Publish your work in this journal}

The International Journal of Nanomedicine is an international, peerreviewed journal focusing on the application of nanotechnology in diagnostics, therapeutics, and drug delivery systems throughout the biomedical field. This journal is indexed on PubMed Central,

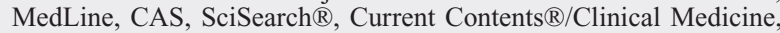

\section{Dovepress}

Journal Citation Reports/Science Edition, EMBase, Scopus and the Elsevier Bibliographic databases. The manuscript management system is completely online and includes a very quick and fair peer-review system, which is all easy to use. Visit http://www.dovepress.com/ testimonials.php to read real quotes from published authors. 